\title{
Pengaruh Pupuk Hayati Bioboost dan Pupuk Guano terhadap Pertumbuhan dan Hasil Tanaman Kacang Tanah (Arachis hypogeae $\mathbf{L}$.)
}

\author{
The Effect of bioobost bio-fertilizer and guano fertilizer Application on \\ Growth and Yield of Peanut (Arachis hypogeae L.)
}

\author{
Mittha Ulhair ${ }^{1}$, Jumini $^{1}$ dan Nurhayati ${ }^{{ }^{*}}$ \\ ${ }^{1}$ Program Studi Agroteknologi, Fakultas Pertanian, Universitas Syiah Kuala
}

\begin{abstract}
Abstrak
Tanaman kacang tanah merupakan komoditi agrobisnis yang memiliki nilai ekonomi yang cukup tinggi dan salah satu sumber protein dan lemak dalam pola pangan masyarakat Indonesia. Kebutuhan kacang tanah dari tahun ke tahun mengalami peningkatan seiring dengan bertambahnya jumlah penduduk Indonesia, kebutuhan gizi masyarakat, diversifikasi pangan, serta meningkatnya kapasitas industry makanan dan pakan di Indonesia. Namun produksi kacang tanah di dalam negeri belum mencukupi kebutuhan penduduk Indonesia yang masih memerlukan impor dari luar negeri. Oleh sebab itu pemerintah masih terus berusaha untuk meningkatkan produksi melalui intensifikasi dan perluasan areal pertanaman. Penggunaan pupuk hayati bioboost dan pupuk guano sebagai suatu pilihan dalam pengelolaan tanah untuk tujuan pemulihan dan peningkatan kualitas kesuburan tanah terdegradasi. Tujuan penelitian ini adalah Untuk mengetahui pengaruh konsentrasi pupuk hayati bioboost dengan dosis pupuk guano yang sesuai, serta mengetahui ada tidaknya interaksi yang nyata antara konsentrasi pupuk hayati bioboost dengan dosis pupuk guano terhadap pertumbuhan dan hasil tanaman kacang tanah.Penelitian dilakukan di kebun percobaan sektor selatan Fakultas Pertanian Universitas Syiah kuala Darussalam Banda Aceh. Penelitian telah dilaksanakan dari bulan Oktober sampai Desember 2017. Rancangan percobaan yang digunakan dalam penelitian ini adalah rancangan acak kelompok pola faktorial $4 \mathrm{x}$ 3 dengan 3 ulangan. Hasil penelitian menunjukkan bahwa pupuk hayati bioboost berpengaruh sangat nyata terhadap jumlah polong, tetapi berpengaruh tidak nyata terhadap tinggi tanaman umur 14, 21, dan 28 HST, berat polong, jumlah polong bernas, jumlah polong hampa, berat 100 butir biji, berat biji per tanaman dan potensi hasil. Pertumbuhan dan hasil tanaman kacang tanah cenderung lebih baik di jumpai pada konsentrasi $10 \mathrm{ml} / \mathrm{L}$ air. Pemberian dosis pupuk guano berpengaruh sangat nyata terhadap jumlah polong bernas, berpengaruh nyata terhadap jumlah polong, berat biji per tanaman, dan potensi hasil dan berpengaruh tidak nyata terhadap tinggi tanaman umur 14, 21, dan 28 HST, berat polong, jumlah polong hampa dan berat 100 butir biji. Hasil yang cenderung lebih baik dijumpai pada dosis 20 ton/ha. Terdapat interaksi yang sangat nyata antara konsentrasi pupuk bioboost dengan dosis pupuk guano terhadap berat biji per tanaman dan potensi hasil serta nyata pada jumlah polong dan berat 100 butir biji.Kombinasi yang lebih baik dijumpai pada perlakuan konsentrasi pupuk bioboost $5 \mathrm{ml} / \mathrm{Liter}$ air dan dosis pupuk guano 20 ton/ha
\end{abstract}

Kata kunci : Kacang Tanah, Bioboost dan Pupuk Guano.

\begin{abstract}
Peanut is an agricultural commodity with high level of economic value and one of protein and fat sources in Indonesian's food pattern. The need of peanut from year to year increases as the population growth, the need of nutrient for society, food diversification and the capacity of food industry in Indonesia increase. Yet the domestic production of peanut has not reach the level of Indonesian's need yet and needs to be imported from aboard. Hence, the government keeps struggling in order to increase the number of production through intensification and extention ofcultivating area. The use of biological bioboost manure and guano manure as choices in managing the soil in order to recover and increase the quality of degradated soil fertile. This research aims to know the effect of biological bioboost manure concentration and proper dose of guano manure, and to know whether there is a significant interaction between biological bioboost manure concentration and dose of guano manure toward peanut growth and production result. This
\end{abstract}


research is done in pilot-field south sector of Fakultas Pertanian Universitas Syiah kuala Darussalam Banda Aceh. This research has been done during October to December 2017. The experimental plan used in this research is group random plan (RAK) factorial 4 x 3 pattern with 3 iterations. The result shows that biological bioboost manure has significant effect toward the number of beans, yet has no significant effect toward the height of plant age 14, 21 and 28 HST, weight of beans, number of filled out beans, number of empty beans, weight of 100 grain of seed, weight of seed per plant and potentional result. The concentration of bioboost manure tends to get better in effecting the growth and the result of peanut plantation in concentration of $10 \mathrm{ml} / \mathrm{L}$ water. The giving of dose of guano manure has significant effect toward number of filled out beans, number of beans, weight of seed per plant, and potential result yet has no significant effect toward the height of plant age 14, 21 and $28 \mathrm{HST}$, weight of beans, number of empty beans and weight of 100 grain of seed. The result tends to get better in dose of 20 ton/ha.

Keywords :Peanut, Bioboost and Guano Manure.

\section{PENDAHULUAN}

Tanaman kacang tanah merupakan komoditi agrobisnis yang memiliki nilai ekonomi yang cukup tinggi dan salah satu sumber protein dan lemak dalam pola pangan masyarakat Indonesia. Kebutuhan kacang tanah dari tahun ke tahun mengalami peningkatan seiring dengan bertambahnya masyarakat Indonesia, kebutuhan gizi masyarakat, diversifikasi pangan di Indonesia. Namun produksi kacang tanah di Indonesia belum mencukupi kebutuhan. Masyarakat Indonesia masih memerlukan impor dari luar negeri. Oleh sebab itu pemerintah masih terus berusaha untuk meningkatkan produksi melalui intensifikasi dan perluasan areal pertanaman (Adisarwanto, 2000).

Kacang tanah mempunyai nilai ekonomi yang tinggi serta memiliki peran besar dalam memenuhi kebutuhan bahan pangan jenis kacang-kacangan. Kacang tanah memiliki kandungan karbohidrat $12 \%$, lemak $40-50 \%$, protein sebesar $25-$ $30 \%$, serta vitamin B1 dan menempatkan kacang tanah dalam hal pemenuhan gizi setelah tanaman kedelai (Cibro, 2008).

Kebutuhan kacang tanah di Indonesia rata-rata tiap tahun mencapai 900.000 ton/tahun dan terus meningkat setiap tahunnya, sedangkan produksi kacang tanah secara nasional di Indonesia pada tahun 2014 adalah 638.896 ton. Sedangkan pada tahun 2015 mengalami penurunan produksi menjadi 605.449 ton. Hal ini membuat Indonesia mengimpor kacang tanah rata-rata setiap tahunnya mencapai 242.800 ton (DEPTAN, 2016). Berdasarkan data (BPS, 2016), terjadi peningkatan produksi dan luas panen namun produksi kacang tanah masih terus menurun. Sehingga kebutuhan kacang tanah di Indonesia saat ini masih di penuhi dari impor karena produksi kacang tanah dalam negeri belum mencukupi.

Dalam mengatasi permasalahan tingkat produksi tanaman kacang tanah diperlukan teknik budidaya yang tepat (BPS,2015). Langkah strategis untuk memperbaiki teknik budidaya kacang tanah dengan memanfaatkan penggunaan pupuk hayati bioboost dan pupuk guano.

Bioboost merupakan pupuk hayati yang mengandung mikroorganisme yang unggul, dan bermanfaat untuk meningkatkan kesuburan tanah sebagai hasil proses biokimia tanah. Komposisi pupuk bioboost adalah sebagai berikut : Bacillus sp, Cytophaga sp, Azotobacter sp, Azospirillum sp dan Pseudomonas sp. Pupuk bioboost juga diketahui mengandung hormon pertumbuhan alami seperti auksin (IAA), kinetin, sitokinin, giberellin dan zeatin. Manfaat pupuk bioboost yaitu: (1) hasil panen dapat memenuhi standar organik, (2) mempercepat pertumbuhan 
sehingga panen dapat lebih cepat, (3) menghemat penggunaan pupuk kimia 50 sampai dengan $60 \%$, (4) meningkatkan proses biokimia di dalam tanah sehingga unsur P (Phospor) dan K (Kalium) tersedia dalam jumlah yang cukup sehingga mudah diserap oleh tanaman, (5) meningkatkan jumlah pengikatan nitrogen bebas oleh bakteri dan (6) memperbaiki struktur tanah sehingga tanah lebih subur (Ratna, 2000).

Menurut hasil penelitian Soverda (2009), menunjukkan pemberian pupuk hayati bioboost dengan konsentrasi 7,5 mL/liter pada tanaman kedelai varietas Anjasmoro menunjukkan hasil yang terbaik terhadap pengamatan tinggi tanaman, bobot kering tanaman, umur berbunga serta hasil yang tinggi perhektar.

Selain penggunaan pupuk hayati bioboost untuk meningkatkan produksi kacang tanah juga dapat memanfaatkan pupuk guano (kotoran kelelawar), diharapkan dapat meningkatkan pertumbuhan dan hasil tanaman kacang tanah. Penggunaan pupuk anorganik secara berkelanjutan dan dalam jumlah yang banyak dapat mengakibatkan efek negatif terhadap lingkungan (Udiyani dan Setiawan, 2003). Pupuk guano dapat menjadi salah satu alternative sebagai pengganti pupuk anorganik. Pupuk guano menduduki urutan pertama dalam kadar unsur fosfat, dan menduduki urutan tiga terbesar bersama kotoran sapi perah dalam kadar kalium (Prasetyo, 2006).

Menurut penelitian Arif (2012) pemberian pupuk guano pada dosis 20 ton/Ha menunjukkan hasil terbaik pada tanaman jagung manis terutama pada tinggi tanaman, panjang tongkol berkelobot, bobot tongkol, dan bobot brangkasan segar. Selanjutnya hasil penelitian Rani (2012), pemberian pupuk guano pada taraf 7,5 ton/ha atau $18,75 \mathrm{~g} /$ polybag menunjukkan hasil terbaik pada pertumbuhan tanaman tomat terutama pada lebar daun, jumlah daun, dan hasil buah tomat.

Berdasarkan permasalahan di atas, maka perlu dilakukan penelitian mengenai konsentrasi pupuk hayati bioboost dan dosis pupuk guano untuk mengetahui sejauh mana pengaruh terhadap pertumbuhan dan hasil tanaman kacang tanah serta ada tidaknya interaksi dari kedua faktor tersebut.

\section{METODE PENELITIAN}

\section{Tempat dan Waktu Penelitian}

Penelitian dilaksanakan di kebun percobaan sektor selatan Fakultas Pertanian Universitas Syiah kuala Darussalam Banda Aceh yang dilaksanakan dari bulan Oktober sampai dengan Desember 2017

\section{Alat dan Bahan Penelitian}

Alat yang digunakan dalam penelitian ini yaitu cangkul, gembor, garu, meteran, timbangan biasa, timbangan analitik, tali rafia, papan nama, jangka sorong, camera dan alat tulis. Bahan yang digunakan yaitu Benih kacang tanah varietas Hypomal sebanyak 1.152 benih atau sekitar 480g, Pupuk yang digunakan yaitu Pupuk hayati biobost yang diproduksi oleh K-link sebanyak $202.5 \mathrm{ml}$, Pupuk guano sebanyak $38,88 \mathrm{Kg}$, Urea dengan dosis $25 \mathrm{~kg} / \mathrm{ha}(129.6$ g), SP-36 dengan dosis $50 \mathrm{~kg} / \mathrm{ha}(259.2 \mathrm{~g})$, dan $\mathrm{KCl}$ dengan dosis $37,5 \mathrm{~kg} / \mathrm{ha}$ (194.4 g). 


\section{Rancangan Penelitian}

Rancangan penelitian yang digunakan adalah rancangan acak kelompok (RAK) pola faktorial 4 × 3 dengan 3 ulangan. Adapun faktor yang diteliti yaitu konsentrasi pupuk hayati bioboost dengan taraf $0,5,7,5$, dan $10 \mathrm{ml} / \mathrm{L}$ air dan dosis pupuk guano dengan taraf 0,10 dan 20 ton/ha. Dengan demikian terdapat 12 kombinasi perlakuan. Masing-masing perlakuan di ulang sebanyak 3 kali, sehingga penelitian ini mempunyai 36 satuan percobaan.

\section{Pelaksanaan Penelitian Pengolahan Tanah}

Tanah diolah dengan menggunakan cangkul, lahan yang digunakan untuk terlebih dahulu dibersihankan dari sisa-sisa dari tanaman pengganggu. Pengolahan tanah dilakukan 2 minggu sebelum tanam. Selanjutnya bedengan dibentuk dengan ukuran 1,2 $\mathrm{m}$ x 1,2 m dan tinggi bedengan $20 \mathrm{~cm}$ sebanyak 27 bedengan, jarak antar bedengan $40 \mathrm{~cm}$ dan jarak antar ulangan $50 \mathrm{~cm}$.

\section{Pemupukan guano}

Pupuk guano diberikan setelah pembuatan bedengan selesai dengan dosis sesuai dengan perlakuan. Pupuk tersebut diberikan 4 hari sebelum tanam dengan cara menabur rata di atas bedengan, selanjutnya tanah di aduk dengan menggunakan garu agar tercampur dengan pupuk.

\section{Penanaman}

Penanaman dilakukan dengan jarak tanam $25 \mathrm{~cm}$ x $25 \mathrm{~cm}$ dengan membuat lubang tanam kemudian memasukkan 2 benih perlubang tanam dan ditutupi dengan tanah. Pada umur 1 minggu setelah tanam dibuang 1 tanaman.

\section{Pemupukan Urea, KCl, SP-36}

Pupuk dasar yang digunakan adalah pupuk tunggal dengan setengah dosis anjuran yaitu urea dengan dosis $25 \mathrm{~kg} / \mathrm{ha}$ (3,6 g/bedeng), Pupuk SP-36 denga dosis $50 \mathrm{~kg} / \mathrm{ha}(7,2$. g/bedeng), dan $\mathrm{KCl}$ dengan dosis $37,5 \mathrm{~kg} / \mathrm{ha}(5,4 \mathrm{~g} /$ bedeng) dengan sekali pemberian saat pertama penanaman dengan cara larikan

\section{Pemupukan bioboost}

Pupuk hayati bioboost di berikan 3 kali yaitu pada saat 2 hari sebelum tanam, 30 Hari Setelah Tanam (HST), dan 60 HST dengan konsentrasi yang sesuai perlakuan. Pupuk hayati bioboost ini diberikan dengan cara menyiram ke tanah disekitar akar tanaman sebanyak $100 \mathrm{ml} /$ tanaman.

\section{Pemeliharaan}

Pemeliharaan dilakukan dengan penyiraman, penyiangan, dan pembumbunan. Penyiraman dilakukan setiap hari pada pagi dan sore hari atau disesuaikan dengan kondisi cuaca, penyiraman dilakukan dengan mengunakan gembor. Penyiangan pertama dilakukan pada umur 2 minggu setelah tanam, penyiangan kedua dilakukan pada saat tanaman berumur 6 minggu setelah tanam (selesai tanaman berbunga). Penyiangan gulma dilakukan dengan cangkul kecil. Pembumbunan dilakukan dengan mengemburkan tanah yang ada disekitar perakaran tanaman, dan menaikan tanah di sekitar perakaran tanaman.

\section{Pemanenan}

Panen kacang tanah dilakukan dengan ciri-ciri $75 \%$ dari daun-daun tanaman menguning dan polong sudah tua. Ciri-ciri polong yang sudah siap dipanen adalah yang berwarna coklat, keras, dan bila dibuka biji sudah terisi penuh beserta dengan kulit biji yang sudah mulai kelihatan menipis berwarna 
kehitaman. Kacang tanah varietas Hypoma 1 di panen pada umur kurang lebih 94 hari setelah tanam.

\section{Pengamatan}

Tinggi tanaman $(\mathrm{cm})$

Pengamatan dilakukan pada 5 sampel tanaman yang diamati pada umur 2, 3, dan 4 MST (Minggu setelah tanam). Tinggi tanaman diukur dari pangkal batang yang telah di beri tanda, hingga titik tumbuh yang tertinggi.

\section{Berat polong per tanaman $(\mathrm{g})$}

Pengamatan berat polong per tanaman dilakukan dengan menimbang polong kacang tanah yang telah dikering anginkan .

\section{Jumlah polong per tanaman (buah)}

Pengamatan jumlah polong per tanaman dilakukan setelah tanaman di panen.

\section{Jumlah polong bernas per tanaman (buah)}

Penghitungan jumlah polong yang berisi penuh per tanaman dilakukan setelah tanaman di panen.

\section{Jumlah polong hampa per tanaman (buah)}

Pengamatan jumlah polong hampa per tanaman dilakukan dengan menghitung jumlah polong kacang tanah yang tidak berisi penuh.

\section{Berat 100 butir biji (g)}

Penimbangan berat 100 butir biji dilakukan dengan menggunakan timbangan analitik. Biji yang sudah dikering anginkan selama 1 minggu, setelah itu biji diambil secara acak dari setiap unit percobaan.

\section{Berat biji per tanaman (g)}

Pengamatan ini dilakukan setelah panen, dengan menimbang biji yang telah dikeringanginkan selama 7 hari.

\section{Potensi hasil per ha (ton/ha)}

Pengamatan potensi hasil perhektar di peroleh dengan mengunakan rumus sebagai berikut $:$ Hasil $/$ ha $=\frac{\text { luas tanah } 1 \text { ha }}{\text { jarak tanam }} \times$ berat biji pertanaman

\section{Analisis Data Penelitian}

Data hasil pengamatan pada setiap parameter dianalisis dengan anova. Data yang menunjukkan perbedaan yang nyata pada $\mathrm{F}$ hitung maka dilanjutkan dengan Uji Beda Nyata Jujur (BNJ) pada taraf 0,05.

\section{HASIL DAN PEMBAHASAN}

\section{Hasil Penelitian}

\section{Rekapitulasi analisis sidik ragam 5\%}

Rekapitulasi hasil analisis sidik ragam (Uji F) pengaruh konsentrasi pupuk bioboost dan dosis pupuk guano serta interaksi antara keduanya terhadap pertumbuhan dan hasil tanaman kacang tanah dapat dilihat pada Tabel 1. 
Tabel 1. Rekapitulasi hasil analisis ragam (Uji F) pengaruh konsentrasi pupuk bioboost, dosis pupuk guano dan interaksi antara keduanya terhadap pertumbuhan dan hasil tanaman kacang tanah.

\begin{tabular}{clccc}
\hline \multirow{2}{*}{ No } & & \multicolumn{3}{c}{ Perlakuan } \\
\cline { 3 - 5 } & & P & G & P X G \\
\hline 1 & Tinggi Tanaman Kacang Tanah 14 HST & tn & tn & tn \\
2 & Tinggi Tanaman Kacang Tanah 21 HST & tn & tn & tn \\
3 & Tinggi Tanaman Kacang Tanah 28 HST & tn & tn & tn \\
4 & Berat Polong Per Tanaman & tn & tn & tn \\
5 & Jumlah Polong Per Tanaman & $* *$ & $*$ & $*$ \\
6 & Jumlah Polong Bernas Per Tanaman & tn & $* *$ & tn \\
7 & Jumlah Polong Hampa Per Tanaman & tn & tn & tn \\
8 & Berat 100 Butir Biji & tn & tn & $*$ \\
9 & Berat Biji Per Tanaman & tn & $*$ & $* *$ \\
10 & Potensi Hasil & tn & $*$ & $* *$ \\
\hline
\end{tabular}

Keterangan: **: berpengaruh sangat nyata pada taraf 0,$01 ; *$ : Berpengaruh nyata pada taraf 0,05 ; tn: Tidak berpengaruh nyata pada taraf 0,05; P: Pupuk bioboost; G: Pupuk guano; $\mathrm{P}$ x G: Interaksi antara konsentrasi pupuk bioboost dan dosis pupuk guano

\section{Pengaruh Pemberian Pupuk Hayati Bioboost Terhadap Pertumbuhan dan Hasil Tanaman Kacang Tanah}

Rata-rata pertumbuhan dan hasil tanaman kacang tanah akibat perlakuan konsentrasi pupuk hayati bioboost dapat dilihat pada Tabel 2.

Tabel 2. menunjukkan bahwa jumlah polong per tanaman lebih banyak dijumpai pada konsentrasi pupuk hayati bioboost $10 \mathrm{ml} / \mathrm{L}$ air $\left(\mathrm{P}_{3}\right)$ yang berbeda nyata dengan perlakuan konsentrasi $5 \mathrm{ml} /$ liter air $\left(\mathrm{P}_{1}\right)$ dan $7,5 \mathrm{ml} /$ liter air $\left(\mathrm{P}_{2}\right)$, tetapi berbeda tidak nyata dengan konsentrasi $0 \mathrm{ml} /$ liter air $\left(\mathrm{P}_{0}\right)$.

Pada tinggi tanaman umur 14, 21 dan 28 HST menunjukkan bahwa pada perlakuan konsentrasi pupuk hayati booboost berpengaruh tidak nyata, namun tanaman kacang tanah pada umur 28 HST cenderung lebih tinggi dijumpai pada konsentrasi $5 \mathrm{ml} / \mathrm{L}$ air $\left(\mathrm{P}_{1}\right)$. Berat polong cenderung lebih tinggi dijumpai pada perlakuan konsentrasi $10 \mathrm{ml} / \mathrm{L}$ air $\left(\mathrm{P}_{3}\right)$. Pada jumlah polong bernas dan jumlah polong hampa menunjukkan bahwa perlakuan konsentrasi pupuk hayati bioboost berpengaruh tidak nyata, namun jumlah polong bernas cenderung lebih tinggi dijumpai pada konsentrasi $5 \mathrm{ml} / \mathrm{liter}$ air $\left(\mathrm{P}_{1}\right)$. dan jumlah polong hampa cenderung lebih tinggi dijumpai pada konsentrasi $10 \mathrm{ml} /$ liter air $\left(\mathrm{P}_{3}\right)$.

Selanjutnya pada berat 100 butir biji, berat biji per tanaman dan potensi hasil menunjukkan bahwa perlakuan konsentrasi pupuk hayati bioboost berpengaruh tidak nyata, namun pada berat 100 butir biji cenderung lebih tinggi dijumpai pada perlakuan konsentrasi $7,5 \mathrm{ml} /$ liter air $\left(\mathrm{P}_{2}\right)$, sedangkan pada berat biji per tanaman dan potensi hasil cenderung lebih baik dijumpai pada perlakuan konsentrasi $10 \mathrm{ml} /$ liter air $\left(\mathrm{P}_{3}\right)$.

Hasil penelitian menunjukkan bahwa perlakuan konsentrasi pupuk hayati bioboost pada konsentrasi $10 \mathrm{ml} / \mathrm{L}$ air cenderung lebih baik dibandingkan dengan konsentrasi lainnya. Hal ini diduga karena kandungan pupuk hayati bioobost terdapat mikroorganisme unggul yang bermanfaat untuk meningkatkan kesuburan tanah sebagai hasil proses biokimia tanah yang membantu dalam proses 
pertumbuhan dan hasil pada tanaman kacang tanah, dimana mikroorganisme yang terdapat didalam pupuk hayati bioboost yaitu bakteri Azotobacter sp, Azospirillum sp, Bacillus sp, Cytophaga sp dan Pseudomonas sp.

Menurut Sinulingga et all. (2015) keberhasilan penggunaan pupuk hayati tidak hanya dipengaruhi oleh kuantitas mikroba namun salah satunya adalah faktor lingkungan seperti suhu dan curah hujan. Selain itu bahan organik yang rendah juga dapat menunjukkan pengaruh yang tidak nyata. Mikroba mampu hidup bersama tanaman inangnnya sehingga keuntungan diperoleh oleh keduanya. Tanaman inang mendapatkan unsur hara sedangkan mikroba mendapatkan bahan organik yang digunakan untuk aktivitas pertumbuhannya (Muhsin et all., 2017). Bahan organik sangat baik bagi tanaman karena mengandung zat tumbuh dan dapat merangsang pertumbuhan tanaman (Irawan et all., 2016). Selain itu konsentrasi yang tinggi menyebabkan mikroba yang terdapat di dalam tanah lebih banyak sehingga terjadi persaingan antara mikroba dalam memenuhi kebutuhan makanannya.

Hal lain yang perlu diperhatikan dalam pemberian pupuk adalah konsentrasi dari pupuk yang diberikan pada tanaman. Semakin tinggi konsentrasi pupuk yang diberikan pada tanaman maka kandungan unsur hara yang diterima oleh tanaman akan semakin tinggi, Namun pada saat pemberian dengan konsentrasi yang berlebihan dapat mengakibatkan hal buruk bagi pertumbuhan tanaman. Oleh karena itu, pemilihan konsentrasi yang tepat sangat perlu diketahui agar pertumbuhan tanaman menjadi lebuh baik. Sesuai dengan pernyataan Kalay et al. (2016) azotobacter, azospirilium, acinotobacter, dan pseudomonas yang terkandung dalam pupuk menghasilkan hormon pertumbuhan, sehingga pertumbuhan dan hasil meningkat.

Pada umumnya mikroba dalam tanah dapat hidup bersama dengan tanaman inangnya sehingga keduanya mendapatkan keuntungan, mikroba mendapatkan bahan organik untuk aktivitasnya dan tanaman inang juga mendapatkan tambahan unsur hara. Pemberian beberapa mikroba yang bersinergi dalam menyediakan unsur hara seperti Rhizobium sp sebagai penambat Nitrogen, Bacillus sp dan Pseudomonas sp sebagai pelarut posfat dan penghasil fitohormon berperan dalam pertumbuhan kacang tanah (Siregar et al., 2017). Kandungan unsur $\mathrm{P}$ di dalam tanah berfungsi sebagai pertumbuhan dan pembentukan biji kacang tanah. Selain itu kandungan unsur $\mathrm{P}$ juga dapat mempercepat terbentuknya bunga.

Selain mengandung mikroorganisme pupuk hayati Bioboost juga mengandung hormon yang dapat memacu pertumbuhan tanaman dan kandungan mikroorganisme dalam pupuk hayati bioboost dapat meningkatkan pengambilan hara dari tanah. Sejalan dengan pernyataan Wibowo et al.(2009) peningkatan hormon sitokinin dapat meningkatan jumlah cabang dan daun yang akan memacu peningkatan laju fotosintesis sehingga produksi dan hasil kacang tanah akan semakin tinggi. Muhsin et al. (2017) menyatakan bahwa pupuk hayati atau biofertilizer yang mengandung unsur mikroba dapat meningkatkan serapan hara dalam tanah dan udara. Nopiandi dan Anwar (2017) menyatakan bahwa mekanisme pupuk hayati menitikberatkan pada peningkatan aktivitas biologi di dalam tanah untuk mencapai kesuburan dan keseimbangan tanah yang bersifat ramah lingkungan. 
Tabel 2. Rata-rata pertumbuhan dan hasil tanaman kacang tanah akibat perlakuan konsentrasi pupuk hayati bioboost

\begin{tabular}{|c|c|c|c|c|c|c|}
\hline \multirow{2}{*}{\multicolumn{2}{|c|}{ Parameter yang diamati }} & \multicolumn{4}{|c|}{$\begin{array}{l}\text { Pupuk Hayati Bioboost } \\
(\mathrm{ml} / \mathrm{L} \text { air })\end{array}$} & \multirow{2}{*}{$\begin{array}{l}\text { BNJ } \\
0,05\end{array}$} \\
\hline & & $0\left(\mathrm{P}_{0}\right)$ & $5\left(\mathrm{P}_{1}\right)$ & $7,5\left(\mathrm{P}_{2}\right)$ & $10\left(\mathrm{P}_{3}\right)$ & \\
\hline \multirow{3}{*}{ Tinggi tanaman $(\mathrm{cm})$} & $14 \mathrm{HST}$ & 19.51 & 17.46 & 17.18 & 17.47 & - \\
\hline & $21 \mathrm{HST}$ & 30.82 & 31.85 & 32.39 & 31.98 & - \\
\hline & $28 \mathrm{HST}$ & 41.89 & 42.63 & 40.71 & 40.71 & - \\
\hline \multicolumn{2}{|c|}{ Berat polong per tanaman $(\mathrm{g})$} & 24.83 & 22.85 & 23.85 & 26.31 & - \\
\hline \multirow{2}{*}{\multicolumn{2}{|c|}{$\begin{array}{l}\text { Jumlah polong per tanaman (buah) } \\
\text { Jumlah polong bernas per tanaman } \\
\text { (buah) }\end{array}$}} & $16.89 \mathrm{ab}$ & $15.56 \mathrm{a}$ & $15.67 \mathrm{a}$ & $18.67 \mathrm{~b}$ & 2.36 \\
\hline & & 12.22 & 13.56 & 11.22 & 13.33 & - \\
\hline \multicolumn{2}{|c|}{$\begin{array}{l}\text { Jumlah polong hampa per tanaman } \\
\text { (buah) }\end{array}$} & 1.29 & 1.02 & 1.02 & 1.11 & - \\
\hline \multicolumn{2}{|l|}{ Berat 100 butir biji (g) } & 58.91 & 61.27 & 64.61 & 61.56 & - \\
\hline \multicolumn{2}{|c|}{ Berat biji per tanaman (g) } & 19.13 & 19.07 & 19.53 & 19.71 & - \\
\hline \multicolumn{2}{|l|}{ Potensi hasil (ton/ha) } & 3.05 & 3.01 & 3.12 & 3.15 & - \\
\hline
\end{tabular}

Keterangan : Angka yang diikuti oleh huruf yang sama pada baris yang sama berbeda tidak nyata pada taraf $5 \%\left(\mathrm{Uji} \mathrm{BNJ}_{0,05}\right)$

\section{Pengaruh Pemberian Pupuk Guano Terhadap Pertumbuhan dan Hasil Tanaman Kacang Tanah}

Rata-rata pertumbuhan dan hasil tanaman kacang tanah akibat perlakuan dosis pupuk guano dapat dilihat pada Tabel 3.

Tabel 3. menunjukkan bahwa pada jumlah polong per tanaman akibat perlakuan dosis pupuk guano lebih tinggi dijumpai pada dosis 20 ton/ha $\left(\mathrm{G}_{2}\right)$ yang berbeda nyata dengan dosis 10 ton/ha $\left(\mathrm{G}_{1}\right)$, tetapi berbeda tidak nyata dengan 0 ton/ha $\left(\mathrm{G}_{0}\right)$. Pada jumlah polong bernas lebih tinggi dijumpai pada dosis pupuk guano 20 ton/ha $\left(\mathrm{G}_{2}\right)$ yang berbeda nyata dengan dosis 0 ton/ha $\left(\mathrm{G}_{0}\right)$ dan 10 ton/ha $\left(\mathrm{G}_{1}\right)$. Pada berat biji per tanaman dan potensi hasil akibat perlakuan dosis pupuk guano lebih tinggi dijumpai pada dosis 20 ton/ha $\left(\mathrm{G}_{2}\right)$ yang berbeda nyata dengan perlakuan 0 ton/ha $\left(\mathrm{G}_{0}\right)$ tetapi berbeda tidak nyata dengan perlakuan 10 ton/ha $\left(\mathrm{G}_{1}\right)$.

Selanjutnya pada tinggi tanaman umur 14, 21, dan 28 HST akibat perlakuan dosis pupuk guano berpengaruh tidak nyata, namun tanaman cenderung lebih tinggi dijumpai pada umur 28 HST pada dosis 20 ton/ha $\left(G_{2}\right)$. Pada berat polong akibat perlakuan dosis pupuk guano berpengaruh tidak nyata, namun berat polong per tanaman cenderung lebih tinggi dijumpai pada perlakuan konsentrasi 20 ton/ha $\left(\mathrm{G}_{2}\right)$. Jumlah polong hampa cenderung lebih tinggi dijumpai pada perlakuan guano 20 ton/ha $\left(\mathrm{G}_{2}\right)$. Dan pada berat 100 butir biji akibat perlakuan dosis pupuk guano berpengaruh tidak nyata, namun berat 100 butir biji cenderung lebih tinggi dijumpai pada perlakuan 0 ton/ha $\left(\mathrm{G}_{0}\right)$.

Hasil penelitian menunjukkan bahwa perlakuan dosis pupuk guano yang lebih baik dalam meningkatkan produksi kacang tanah adalah pada dosis 20 ton/ha $\left(\mathrm{G}_{2}\right)$. Hal ini diduga unsur hara yang terkandung didalam pupuk guano dapat meningkatkan pertumbuhan dan hasil tanaman kacang tanah. Sejalan dengan penelitian Suwarno dan Idris (2007) Pupuk guano mengandung unsur hara $P$ yang lebih tinggi dibandingkan dengan pupuk organik lainnya. kandungan unsur hara guano yaitu N (8-13\%), P (5-12\%), dan K (1,5-2\%), pupuk kandang 
kotoran sapi yaitu N (1,23\%), P (0,55\%), K (0,69\%) dan pupuk kandang kotoran ayam yaitu $\mathrm{N}(3,77 \%), \mathrm{P}(1,89 \%)$ dan $\mathrm{K}(1,76 \%)$. Hal ini juga sependapat dengan yang dinyatakan oleh Lingga dan Marsono (2004) bahwa pupuk guano mengandung unsur hara penting yaitu : N (8-13\%), P (5-12\%), K (1,5-2\%), Ca (97,5-11\%), $\mathrm{Mg}(0,5-1 \%)$ dan $\mathrm{S}(2-3,5 \%)$.

Pemberian pupuk guano sangat baik untuk memperbaiki kesuburan tanah secara berkelanjutan. Menurut Sufardi (2012) pupuk organik berperan dalam memperbaiki sifat biologi, fisika, dan kimia tanah serta lingkungan. Bahan organik juga sangat berperan sebagai sumber energi dan makanan bagi mikroba tanah sehingga dapat meningkatkan aktifitas mikroba dalam menyediakan unsur hara yang ada didalam tanah.

Pemberian pupuk guano juga dapat memperbaiki struktur tanah sehingga pori-pori tanah menjadi lebih baik. Menurut Sufardi (2012) pupuk organik berperan mengubah pengikat butiran primer tanah menjadi sekunder dalam pembentukan pupuk. Sehingga akan mempengaruhi aerasi tanah, penyediaan air dan suhu tanah. Pupuk organik memiliki fungsi kimia yang penting seperti: penyediaan hara makro dan mikro. Meskipun unsur hara yang terkandung di dalam pupuk organik sedikit akan tetapi lengkap.

Tabel 3. Rata-rata pertumbuhan dan hasil tanaman kacang tanah akibat perlakuan dosis pupuk guano

\begin{tabular}{|c|c|c|c|c|c|}
\hline \multirow{2}{*}{\multicolumn{2}{|c|}{ Parameter yang diamati }} & \multicolumn{3}{|c|}{ Pupuk Guano (ton/ha) } & \multirow{2}{*}{$\begin{array}{l}\text { BNJ } \\
0,05\end{array}$} \\
\hline & & $0\left(\mathrm{G}_{0}\right)$ & $10\left(\mathrm{G}_{1}\right)$ & $20\left(\mathrm{G}_{2}\right)$ & \\
\hline \multirow{3}{*}{ Tinggi tanaman $(\mathrm{cm})$} & $14 \mathrm{HST}$ & 18.83 & 17.48 & 17.40 & - \\
\hline & $21 \mathrm{HST}$ & 31.53 & 31.74 & 32.00 & - \\
\hline & $28 \mathrm{HST}$ & 40.29 & 41.85 & 42.45 & - \\
\hline \multicolumn{2}{|c|}{ Berat polong per tanaman $(\mathrm{g})$} & 23.20 & 22.95 & 26.77 & - \\
\hline \multicolumn{2}{|c|}{ Jumlah polong per tanaman (buah) } & $16.42 \mathrm{ab}$ & $15.84 \mathrm{a}$ & $17.83 \mathrm{~b}$ & 1,85 \\
\hline \multicolumn{2}{|c|}{ Jumlah polong bernas per tanaman(buah) } & $10.75 \mathrm{a}$ & $11.92 \mathrm{a}$ & $15.08 \mathrm{~b}$ & 2.45 \\
\hline \multicolumn{2}{|c|}{ Jumlah polong hampa per tanaman (buah) } & 1.12 & 1.05 & 1.17 & - \\
\hline \multicolumn{2}{|c|}{ Berat 100 butir biji (g) } & 61.66 & 61.07 & 61.04 & - \\
\hline \multicolumn{2}{|c|}{ Berat biji per tanaman $(\mathrm{g})$} & $18.17 \mathrm{a}$ & $19.17 \mathrm{~b}$ & $20.69 \mathrm{~b}$ & 2.23 \\
\hline \multicolumn{2}{|l|}{ Potensi hasil (ton/ha) } & $2.90 \mathrm{a}$ & $3.06 \mathrm{ab}$ & $3.28 \mathrm{~b}$ & 0,34 \\
\hline
\end{tabular}

Keterangan : Angka yang diikuti oleh huruf yang sama pada baris yang sama berbeda tidak nyata pada taraf $5 \%\left(\mathrm{Uji} \mathrm{BNJ}_{0,05}\right)$

\section{Interaksi Pemberian Pupuk Hayati Bioboost dengan Pupuk Guano Terhadap Pertumbuhan dan Hasil Tanaman Kacang Tanah}

Rata-rata interaksi antara konsentrasi pupuk hayati bioboost dengan dosis pupuk guano terhadap berat biji per tanaman, potensi hasil, jumlah polong per tanaman, dan berat 100 butir biji dapat dilihat pada Tabel 4 .

Pada tabel 4 menunjukkan bahwa terdapat interaksi yang sangat nyata antara konsentrasi pupuk bioboost dengan dosis pupuk guano terhadap berat biji per tanaman dan potensi hasil, interaksi nyata terhadap jumlah polong dan berat 100 butir biji. Berat biji per tanaman dan potensi hasil lebih baik terdapat pada konsentrasi $5 \mathrm{ml} / \mathrm{L}$ air dengan dosis pupuk guano 20 ton/ha. Selanjutnya jumlah polong lebih baik terdapat pada konsentrasi pupuk bioboost $10 \mathrm{ml} / \mathrm{L}\left(\mathrm{P}_{3}\right)$ dengan 
dosis pupuk guano 0 ton/ha $\left(\mathrm{G}_{0}\right)$ dan pada berat 100 biji kering kombinasi terbaik didapat pada konsentrasi $10 \mathrm{ml} / \mathrm{L}\left(\mathrm{P}_{3}\right)$ dengan dosis pupuk guano 20 ton/ha $\left(\mathrm{G}_{2}\right)$

Hasil penelitian menunjukkan bahwa pertumbuhan dan hasil tanaman kacang tanah yang lebih baik dijumpai pada perlakuan konsentrasi pupuk bioboost $5 \mathrm{ml} / \mathrm{L}$ air $\left(\mathrm{P}_{1}\right)$ dan dosis pupuk guano 20 ton/ha $\left(\mathrm{G}_{2}\right)$. Hal ini diduga pemberian pupuk bioboost $5 \mathrm{ml} / \mathrm{L}$ air dan pupuk guano 20 ton/ha dapat memperbaiki sifat fisika, biologi dan kimia tanah serta menambah unsur hara yang terdapat didalam tanah, sehingga pertumbuhan dan hasil tanaman kacang tanah memberikan hasil yang maksimal. Kombinasi pupuk bioboost dengan dosis pupuk guano yang tepat dapat memberikan respon yang maksimal terhadap pertumbuhan dan produksi tanaman kacang tanah. Menurut Lingga (2000) pemupukan yang tepat pada umumnya bertujuan untuk memelihara atau memperbaiki kesuburan tanah dan menambah unsur hara yang diperlukan oleh tanaman. Tindakan ini mempengaruhi hubungan tanah dengan tumbuh-tumbuhan, dimana secara langsung atau tidak akan dapat juga menyumbangkan bahan makanan kepada tanaman yang tumbuh di daerah tersebut.

Tabel 4. Rata-rata berat biji per tanaman, potensi hasil, jumlah polong dan berat 100 butir biji akibat interaksi pupuk bioboost dengan pupuk guano

\begin{tabular}{|c|c|c|c|c|c|}
\hline \multirow{2}{*}{ Parameter } & \multirow{2}{*}{$\begin{array}{c}\text { Perlakuan } \\
\text { Pupuk bioboost } \\
\text { (ml/L air) }\end{array}$} & \multicolumn{3}{|c|}{ Pupuk guano (ton/ha) } & \multirow{2}{*}{$\begin{array}{l}\text { BNJ } \\
0,05\end{array}$} \\
\hline & & $0(\mathrm{G} 0)$ & $10(\mathrm{G} 1)$ & $20(\mathrm{G} 2)$ & \\
\hline \multirow[t]{4}{*}{$\begin{array}{l}\text { Berat Biji Per } \\
\text { Tanaman }(g)\end{array}$} & $0(\mathrm{P} 0)$ & $18.67 \mathrm{Aa}$ & 18.70 Aab & $19.82 \mathrm{Aa}$ & \multirow{4}{*}{5.54} \\
\hline & $5(\mathrm{P} 1)$ & $20.75 \mathrm{Ba}$ & $14.46 \mathrm{Aa}$ & $22.00 \mathrm{Ba}$ & \\
\hline & $7,5(\mathrm{P} 2)$ & $15.98 \mathrm{Aa}$ & $21.97 \mathrm{Bb}$ & $20.64 \mathrm{ABa}$ & \\
\hline & $10(\mathrm{P} 3)$ & $17.27 \mathrm{Aa}$ & $21.56 \mathrm{Ab}$ & $20.31 \mathrm{Aa}$ & \\
\hline \multirow[t]{4}{*}{$\begin{array}{l}\text { Potensi Hasil } \\
\text { (ton/ha) }\end{array}$} & $0(\mathrm{P} 0)$ & $2.98 \mathrm{Aa}$ & $2.99 \mathrm{Aab}$ & $3.17 \mathrm{Aa}$ & \multirow{4}{*}{0.85} \\
\hline & $5(\mathrm{P} 1)$ & $3.32 \mathrm{Ba}$ & $2.31 \mathrm{Aa}$ & $3.41 \mathrm{Ba}$ & \\
\hline & $7,5(\mathrm{P} 2)$ & $2.55 \mathrm{Aa}$ & $3.51 \mathrm{Ab}$ & $3.30 \mathrm{Aa}$ & \\
\hline & $10(\mathrm{P} 3)$ & $2.76 \mathrm{Aa}$ & $3.44 \mathrm{Ab}$ & $3.25 \mathrm{Aa}$ & \\
\hline \multirow[t]{4}{*}{$\begin{array}{l}\text { Jumlah polong } \\
\text { Per Tanaman } \\
\text { (buah) }\end{array}$} & $0(\mathrm{P} 0)$ & 15.33 Aab & 16.00 Aab & $19.33 \mathrm{Aa}$ & \multirow{4}{*}{4.59} \\
\hline & $5(\mathrm{P} 1)$ & 15.67 Aab & 14.67 Aab & $16.33 \mathrm{Aa}$ & \\
\hline & $7,5(\mathrm{P} 2)$ & $15.00 \mathrm{ABa}$ & $13.67 \mathrm{Aa}$ & $18.33 \mathrm{Aa}$ & \\
\hline & 10 (P3) & $19.67 \mathrm{Ab}$ & $19.00 \mathrm{Ab}$ & $17.33 \mathrm{Ab}$ & \\
\hline \multirow[t]{4}{*}{$\begin{array}{l}\text { Berat } 100 \text { Butir } \\
\text { Biji (g) }\end{array}$} & $0(\mathrm{P} 0)$ & $62.67 \mathrm{Aa}$ & $61.55 \mathrm{Aa}$ & $52.51 \mathrm{Aa}$ & \multirow{4}{*}{18.22} \\
\hline & $5(\mathrm{P} 1)$ & $66.51 \mathrm{Aa}$ & $61.09 \mathrm{Aa}$ & 56.21 Aab & \\
\hline & $7,5(\mathrm{P} 2)$ & $61.55 \mathrm{Aa}$ & $58.84 \mathrm{Aa}$ & $73.45 \mathrm{Ab}$ & \\
\hline & $10(\mathrm{P} 3)$ & $55.89 \mathrm{Aa}$ & $66.80 \mathrm{Aa}$ & $61.99 \mathrm{Aab}$ & \\
\hline
\end{tabular}

Keterangan : Angka diikuti oleh huruf yang sama (Huruf kapital dilihat menurut baris dan huruf kecil dilihat menurut kolom) berbeda tidak nyata pada taraf $5 \%\left(\mathrm{BNJ}_{0,05}\right)$.

KESIMPULAN DAN SARAN 
Hasil penelitian menunjukkan bahwa konsentrasi pupuk hayati bioboost berpengaruh sangat nyata terhadap jumlah polong dan berpengaruh tidak nyata terhadap tinggi tanaman 14, 21, dan 28 HST, berat polong, jumlah polong bernas, jumlah polong hampa, berat 100 butir biji, berat biji per tanaman, dan potensi hasil. Jumlah polong yang lebih banyak terdapat pada konsentrasi pupuk bioboost $10 \mathrm{ml} / \mathrm{L}$ air. Dosis pupuk guano berpengaruh sangat nyata terhadap jumlah polong bernas, berpengaruh nyata pada jumlah polong, berat biji per tanaman dan potensi hasil dan berpengaruh tidak nyata terhadap tinggi tanaman 14, 21, dan 28 HST, berat polong, jumlah polong hampa dan berat 100 butir biji. Hasil tanaman kacang tanah yang lebih baik terdapat pada dosis 20 ton/ha. Terdapat interaksi yang sangat nyata antara konsentrasi pupuk bioboost dengan dosis pupuk guano terhadap berat biji per tanaman dan potensi hasil serta berpengaruh nyata perlakuan jumlah polong dan berat 100 butir biji.Kombinasi yang lebih baik dijumpai pada perlakuan konsentrasi pupuk bioboost $5 \mathrm{ml} /$ Liter air dan dosis pupuk guano 20 ton/ha.Perlu dilakukan penelitian lebih lanjut dengan penggunaan konsentrasi pupuk bioboost yang dikombinasikan dengan dosis pupuk guano untuk mendapatkan hasil yang lebih baik lagi.

\section{DAFTAR PUSTAKA}

Adisarwanto. T, 2005, Meningkatkan Produksi Kacang Tanah di Lahan Sawah dan Lahan Kering. Penebar Swadaya. Jakarta. 88 hal.

Bell, M.J., B. Sukarno dan A.A. Rahmianna. 1992. Effect of photoperiod, temperature and irradiance on peanut growth and development. p. 8594. In Peanut Improvement : A case study in Indonesia. Proc. of an ACIAR/AARD/QDPI Collaboraative review meeting held at Malang, East Java, Indonesia, 19-23 August, 1991. ACIAR Proc. No. 40. 108 p.

Bertham, Y. H. 2002. Potensi Pupuk Hayati alam Peningkatan Produktivitas acang Tanah Dan Kedelai Pada anah Seri Kandanglimun Bengkulu. urnal Ilmu - Ilmu Pertanian ndonesia, olume 4, No.1,2002, Hlm 8 - 26. Program Studi Ilmu Tanah akultas Pertanian Universitas engkulu. Bengkulu.

[BPS] Badan Pusat Statistik . 2016. Tabel Produksi Kacang Tanah. Diakses dari www.bps.go.id. Diakses tanggal 13 april 2017.

[BPS] Badan Pusat Statistik. 2015. Data Strategis BPS. BPS. Jakarta.

[DEPTAN] Departemen Pertanian. 2016. Road Map Peningkatan Produksi Kacang Tanah dan Kacang Hijau Tahun 2015-2016. Jakarta

Adisarwanto, T. 2000. Meningkatkan Produksi Kacang Tanah di Lahan Sawah dan Lahan Kering. Penebar Swadaya. Jakarta. 9 hal.

Amrizal dan Arif. 2012. Effect of The Organic Fertilizers Guano and Tithonia (Tithinia diversifiola) On The Growth And Yield Of Sweet Corn (Zea Mays saccharata Sturt). Hasil Penelitian Tanaman Pangan: 5 hal.

Chusnia. W., Tini, S. Dan Salamun. 2012. Kajian Aplikasi Pupuk Hayati dalam Meningkatkan Pertumbuhan dan Produksi Tanaman Kacang Hijau (Vigna radiata L.) pada Polybag. (Online). (http://biologi.fst.unair.ac.id/wp-content/uploads/2012/04/jurnalWilda.pdf., Diaskes 29 April 2018). 
Cibro, M.A. 2008. Respon Beberapa Varietas Kacang Tanah (Arachis hypogaea L.) Terhadap Pemakaian Mikoriza Pada Berbagai Cara Pengolahan Tanah. Universitas Sumatera Utara. Medan. http://tanamanpangan.deptan.go.id., 2012. Direktoral Jendral Tanaman Pangan. diakses tanggal 14 Maret 2017.

Lingga, Pinus. 2002. Petunjuk Penggunaan Pupuk. Penebar Swadaya. Jakarta.

Manuhuttu A. P., H. Rehatta, dan J. J. G. Kailola. 2014. Pengaruh konsentrasi pupuk hayati bioboost terhadap peningkatan produksi tanaman selada (Lactuca sativa L). Fakultas Pertanian Universitas Pattimura. Agrologia: $3(1): 1-27$

Pitojo, S. 2005. Benih Kacang Tanah. Penerbit Kanisius. Yogyakarta. 75 hal.

Prasetyo S,2006. Guano bahan pupuk organik yang diremehkan. http://jurnalbumi.wordpress.com/2006/01/18/guano-bahan-pupukorganik-yang-diremehkan-2/.

Purwono, dan H.Purnamawati. 2007. Budi daya 8 Jenis Tanaman Pangan Unggul. PenebarSwadaya.Bogor

Rani, W. 2012. Respon tanaman tomat (Lycopersicum esculentum Mill.) varietas victory terhadap pemberian pupuk guano dan mulsa jerami padi. Tesis. Program Studi Agroteknologi, Fakultas Sains dan Teknologi Universitas Islam Negeri Sunan Gunung Djati, Bandung.

Rahmadsyah.A., dan Riana. 2014. Manfaat pupuk guano. http://www.jitunews.com/read/5373/banyaknya-manfaat-pupuk-guano.

Diakses pada tanggal 12 Juli 2018.

Ratna D. I, 2002. Pengaruh Kombinasi Pupuk Hayati dengan Pupuk Organik Cair terhadap Kualitas dan Kuantitas Hasil Tanaman Teh (Camelia sinensis L.) O. Kutze) Klon Gambung 4. Jurnal Ilmu Pertanian $10:$ 17-25.

Soverda.N., dan Tiur. H. 2009. Respon tanaman kedelai (Glycine max (L) Merril.) terhadap pemberian berbagai konsentrasi pupuk hayati. Jurnal Agronomi. $13(1):-12$.

Sumarno. 2003. Teknik Budidaya Kacang Tanah. Sinar Baru Algensindo. Bandung

Suprapto, H. S. 2004. Bertanam Kacang Tanah. Penebar Swadaya. Jakarta. 32 hal.

Suwarno dan K. Idris. 2007. Potensi dan Kemungkinan Penggunaan Guano Secara Langsung Sebagai Pupuk Di Indonesia. Jurnal Tanah dan Lingkungan. Vol.9

(1):

37

43.

Trustinah, E. Guhardja, dan W. Gunarso. 1987a. Perkembangan polong kacang tanah (Arachis hypogaea (L.) Merr.). Penelitian Palawija, 2(1): 56-60.

Udiyani PM, Setiawan MB, 2003. Kajian terhadap pencemaran lingkungan didaerah petanian berdasarkan data radioaktivitas alam.http://digilib.batan.go.id/eprosiding/

File\%20Prosiding/Lingkungan/Bapeten/artikel/Pande-Made-Udiyani172.pdf. Diunduh tanggal 14 Maret 2017

Wawan Irwan, A. Wahyudi, dan C. Suherman, 2006. Pengaruh Pupuk Organik terhadap Hasil Kedelai (Glicine max (L.) Merr) dalam SistemTumpangsari dengan Sorghum (Shorghumbicolor (L.) di Jatinangor 